\title{
PENGARUH KEPEMILIKAN NEGARA DAN ASING TERHADAP CORPORATE RISK TAKING
}

\author{
Indah Kurniawati \\ Email: indah_kurnia48@yahoo.co.id / indah-k-11@feb.unair.ac.id \\ Puput Tri Komalasari \\ Departemen Manajemen Fakultas Ekonomi dan Bisnis Universitas Airlangga
}

\begin{abstract}
This study aimed to investigate the effect of state ownership and foreign ownership of corporate risk taking as well as the control variable return on assets (ROA) and the size of the companies that influence the corporate risk taking. The sample of this study was 181 companies from non-financial companies listed on the Indonesia Stock Exchange in 20102013. The analysis technique used is multiple linear regression analysis. The results obtained are state ownership significant negative effect on the corporate risk taking and foreign ownership is significant positive effect on corporate risk taking. In the control variable is return on assets (ROA) significant positive effect on corporate risk taking and the size of the company significant negative effect on corporate risk taking.
\end{abstract}

Keywords: corporate risk taking, earnings volatility, state ownership, foreign ownership, return on assets (ROA), the size of the company.

\section{Pendahuluan}

Kelemahan dalam sistem tata kelola perusahaan di Asia telah banyak dikaitkan dengan penyebab utama dari krisis yang terjadi tahun 1997 (Dickinson dan Mullineux, 2001). Munculnya isu mengenai lemahnya corporate governance ini juga disebabkan oleh terjadinya pemisahan antara kepemilikan dengan pengendalian perusahaan. Salah satu isu yang paling penting dan kontroversial mengenai corporate governance adalah mengenai struktur kepemilikan saham yang terkait dengan peningkatan kinerja perusahaan dalam hal laba yang akan dihasilkan oleh perusahaan.

Suatu perusahaan atau bisnis akan mengalami masalah utama untuk memperoleh laba perusahaan di masa mendatang yaitu dalam pengambilan risiko perusahaan (corporate risk taking). Risiko merupakan faktor penting yang harus dipertimbangkan dalam mengambil keputusan investasi. Manajemen perusahaan didalam mengambil keputusan terkait risiko perusahaan memiliki karakter yang berbeda-beda. Jenis karakter eksekutif dalam manajemen perusahaan terbagi menjadi dua yaitu risk averse (menghindari risiko) atau risk taking (berani mengambil risiko). Pembeda diantara kedua jenis eksekutif tersebut tercemin pada besar kecilnya risiko perusahaan (corporate risk) yang ada (Budiman dan Setiyono, 2012). Laba perusahaan merupakan sebuah indikator baik buruknya sebuah perusahaan dalam mengelola kegiatan bisnisnya. Kenyataannya, perusahaan tidak selalu 


\section{Indah Kurniawati \\ Puput Tri Komalasari}

memiliki laba yang terus meningkat, melainkan mengalami naik turun di sepanjang tahun operasinya. Pergerakan naik turunnya laba perusahaan disebut dengan volatilitas laba. Volatilitas laba mengindikasikan pengambilan risiko perusahaan dari laba yang dihasilkan perusahaan setiap tahunnya. Volatilitas laba inilah yang mempengaruhi pengambilan keputusan oleh para pemegang kepentingan atau stakeholders perusahaan tersebut dan menjadi indikator untuk menunjukkan risiko bisnis perusahaan.

Konflik keagenan dapat terjadi antara manajer dan pemilik dan juga antara pemegang saham mayoritas dan minoritas. Seperti yang di ungkapkan oleh Jensen \& Meckling (1976) bahwa agency conflict muncul akibat adanya pemisahan antara kepemilikan dan pengendalian perusahaan. Dalam teori keagenan telah dijelaskan bagaimana pihak-pihak yang terlibat dalam perusahaan yaitu manajer, pemilik perusahaan dan kreditor akan berperilaku, karena pada dasarnya mereka memiliki kepentingan yang berbeda. Struktur kepemilikan pada penelitian ini menggunakan kepemilikan negara dan kepemilikan asing. Kepemilikan negara yang diwakili pemerintah, bertindah risk averse terhadap pengambilan risiko perusahaan dikarenakan pemerintah mempunyai tujuan lain yang utama yaitu tujuan politik. Kepemilikan asing meliputi pihak-pihak dari luar negeri baik individu maupun institusional, bertindah risk taking terhadap pengambilan risiko perusahaan dikarenakan investor asing mempunyai kemampuan, keahlian, pengetahuan dan kecanggihan teknologi yang dimiliki untuk membuat perusahaan lebih maju atau berkembang lagi yaitu dengan melakukan ekspansi atau membuka cabang perusahaan yang baru.

\section{Landasan Teori dan Pengembangan Hipotesis}

\subsection{Landasan Teori}

\subsubsection{Teori Keagenan ( Agency theory )}

Dalam mengaitkan antara struktur kepemilikan untuk membuat keputusan manajemen perusahaan dalam corporate risk taking yaitu menggunakan teori keagenan. Teori ini menjelaskan hubungan antara dua pihak yang memiliki perbedaan kepentingan terkait dengan pengelolaan perusahaan (Jensen dan Meckling, 1976). Misalnya, antara pemilik (principal) dan eksekutif (agent) perusahaan. Kedua pihak mungkin memiliki perbedaan preferensi. Pemilik mungkin akan mengharapkan return yang menarik atas investasi mereka, sementara eksekutif perusahaan mungkin mengharapkan keleluasaan dalam menjalankan perusahaan. Pemilik mungkin mengharapkan eksekutif perusahaan tidak mengambil proyek yang memiliki risiko tinggi agar tidak mengurangi kemungkinan keuntungan mereka. Sementara eksekutif perusahaan ingin mengambil proyek berisiko tinggi, agar ketika berhasil mereka akan dihargai pula dengan setimpal. Perbedaan tujuan itulah yang menyebabkan terjadinya conflict of interest di antara pihak agen dan prinsipal. Konflik keagenan timbul karena bentroknya kepentingan antara manajer dan para pemilik 


\section{Jurnal Manajemen Teori dan Terapan \\ Tahun 7. No.2, Agustus 2014}

saham (shareholders). Manajer punya kewajiban untuk memaksimumkan kesejahteraan para pemegang saham, tetapi di sisi lain manajer juga mempunyai kepentingan untuk memaksimumkan kesejahteraan mereka sendiri. Namun, para pemilik (shareholders) juga ingin perusahaannya dapat menghasilkan laba yang tinggi sehingga dapat meningkatkan kesejahteraan mereka.

\subsubsection{Corporate Governance}

Corporate governance muncul karena terjadi pemisahan antara kepemilikan dengan pengendalian perusahaan, atau sering kali dikenal dengan istilah masalah keagenan. Permasalahan keagenan dalam hubungannya antara pemilik modal dengan manajer adalah bagaimana sulitnya pemilik dalam memastikan bahwa dana yang ditanamkan tidak diambil alih atau diinvestasikan pada proyek yang tidak menguntungkan sehingga tidak mendatangkan return. Corporate governance diperlukan untuk mengurangi permasalahan keagenan antara pemilik dan manajer. Corporate governance merupakan tata kelola perusahaan yang menjelaskan hubungan antara berbagai partisipan dalam perusahaan yang menentukan arah kinerja perusahaan.

Beberapa konsep tentang corporate governance antara lain yang dikemukakan oleh Shleifer and Vishny (1997) yang menyatakan corporate governance berkaitan dengan cara atau mekanisme untuk meyakinkan para pemilik modal dalam memperoleh return yang sesuai dengan investasi yang telah ditanam. Struktur kepemilikan termasuk kedalam mekanisme corporate governance, sehingga Mekanisme corporate governance merupakan suatu prosedur dan hubungan yang jelas antara pihak yang mengambil keputusan dengan pihak yang melakukan kontrol atau pengawasan terhadap keputusan.

\subsubsection{Corporate Risk Taking}

Corporate risk taking merupakan pengambilan risiko perusahaan dan risiko perusahaan mencerminkan penyimpangan atau deviasi standar dari earning baik penyimpangan yang bersifat kurang dari yang direncanakan atau mungkin lebih dari yang direncanakan. Semakin besar deviasi earning perusahaan mengindikasikan semakin besar pula risiko yang ada sehingga risiko merupakan faktor penting yang harus dipertimbangkan dalam mengambil keputusan investasi. Besar kecilnya risiko yang terkandung dalam alternatif investasi akan mempengaruhi laba yang diharapkan dari investasi tersebut.

Manajemen perusahaan didalam mengambil keputusan terkait risiko perusahaan memiliki karakter yang berbeda-beda. Jenis karakter eksekutif dalam manajemen perusahaan terbagi menjadi dua yaitu risk averse atau risk taking. Pembeda diantara kedua jenis eksekutif tersebut tercemin pada besar kecilnya risiko perusahaan (corporate risk) yang ada (Budiman dan Setiyono, 2012). Seorang manajer dengan sifat risk averse biasanya lebih memilih segala tindakan dengan risiko yang rendah walaupun hal ini dapat menyebabkan keuntungan yang didapatkan kecil. Tipe risk averse sangat mengutamakan keamanan atau kestabilan dibandingkan memperoleh keuntungan besar tapi berisiko. Beda halnya dengan 


\section{Indah Kurniawati \\ Puput Tri Komalasari}

risk taking, seorang manajer yang memiliki sifat risk taking lebih berani dalam mengambil risiko besar dengan tujuan untuk mendapatkan keuntungan yang besar pula.

Pengambilan risiko perusahaan dapat dilihat dari jenis karakter manajemen perusahaan yang nantinya akan mempengaruhi laba yang dihasilkan dari keputusan dalam pengambilan risiko perusahaan. Laba perusahaan merupakan sebuah indikator baik buruknya sebuah perusahaan dalam mengelola kegiatan bisnisnya. Kemampuan menghasilkan laba oleh perusahaan sangat didukung oleh kemampuan manajemen memaksimalkan sumber daya yang dimiliki perusahaan dan kondisi pasar tempat perusahaan berada. Perusahaan tidak selalu memiliki laba yang terus meningkat, melainkan mengalami naik turun di sepanjang tahun operasinya. Pergerakan naik turunnya laba perusahaan disebut dengan volatilitas laba. Pengukuran untuk pengambilan risiko perusahaan dengan menggunakan standar deviasi yang merupakan perhitungan dalam volatilitas laba. Volatilitas laba yang tinggi mengindikasikan bahwa proyek yang diambil mengandung risiko yang tinggi pula sedangkan volatilitas laba yang rendah mengindikasikan bahwa proyek yang diambil mengandung risiko yang rendah pula.

\subsubsection{Struktur Kepemilikan}

\subsubsection{Kepemilikan negara}

Pada kepemilikan negara yang diwakili oleh pemerintah, pada suatu negara umumnya terdapat pada perusahaan milik negara atau BUMN ataupun perusahaan milik negara yang sudah go public. Pandangan politik terhadap BUMN bahwa perusahaan publik kurang efisien karena melayani kepentingan para politisi (Boycko, Shleifer dan Vishny, 1996), yaitu bahwa tujuan pemerintah tidak memaksimalkan keuntungan atau nilai pasar melainkan meningkatkan lapangan kerja dan pembangunan daerah sebagai pencitraan dari pemerintah agar pada pemilu mendatang dipilih kembali untuk memimpin. Akibatnya, pemerintah kurang maksimal dalam mencari perbaikan kinerja dengan tidak mengambil proyek berisiko karena proyek yang berisiko akan menyebabkan oposisi dari karyawan / pemilih pada pemilu. Manajer pada perusahaan BUMN bersifat risk averse yaitu dengan menghindari proyek yang berisiko tinggi meskipun keuntungan yang didapatkan kecil.

Pemerintah dapat mengintervensi kinerja perusahaan demi kepentingan pemerintah semata. Pemerintah biasanya melakukan intervensi dalam perdagangan dengan mendukung perusahaan-perusahaan domestik dalam kegiatan ekspor. Motif-motif yang mendasari pemerintah melakukan intervensi dalam perdagangan domestik yang paling utama yaitu motif politik dan lainnya pada kegiatan ekonomi, sosial dan budaya. Politik mendorong pemerintah untuk melakukan berbagai kebijakan seperti melindungi pekerja, melindungi keamanan nasional, sebagai respon terhadap perilaku kebijakan perdagangan negara lain yang tidak adil dan mempengaruhi negara-negara lain, dengan begitu maka pemerintahan yang sedang berkuasa mendapatkan kembali hati rakyatnya ketika pemilihan umum selanjutnya (Daniels, et.al. 2007: 172). 


\section{Jurnal Manajemen Teori dan Terapan \\ Tahun 7. No.2, Agustus 2014}

Pemerintah kurang maksimal dalam mencari perbaikan kinerja dan juga manajemen perusahaan bersifat risk averse dengan menghindari proyek dengan risiko yang tinggi karena lebih mengutamakan keamanan atau kestabilan dari laba yang diperoleh. Selain itu, adanya sebagian kepemilikan saham perusahaan oleh negara mendorong perusahaan untuk mengambil investasi yang konservatif atau proyek yang kurang berisiko.

\subsubsection{Kepemilikan Asing}

Kepemilikan asing merupakan proporsi saham biasa perusahaan yang dimiliki oleh perorangan, badan hukum, pemerintah serta bagian-bagiannya yang berstatus luar negeri atau perorangan, badan hukum, pemerintah yang bukan berasal dari Indonesia. Kepemilikan asing dalam perusahaan merupakan pihak yang dianggap concern terhadap peningkatan good corporate governance (Fauzi, 2006). Kepemilikan asing dapat menjadi salah satu pendukung mekanisme corporate governance, dimana perusahaan dengan kepemilikan asing ini akan meningkatkan persaingan pasar di Indonesia. Peningkatan persaingan ini memaksa perusahaan untuk selalu melakukan peningkatan teknologi dan perbaikan di dalam corporate governance sehingga terdapat keselarasan antara kepentingan manajer, investor, dan stakeholders lainnya.

Perusahaan dengan mayoritas kepemilikan asing memiliki manajemen perusahaan yang lebih agresif atau risk taking sehingga berani untuk mengambil risiko yang tinggi dengan menghasilkan laba yang tinggi pula. Keberanian tersebut juga diimbangi dengan kemampuan, keahlian, pengetahuan dan kecanggihan teknologi yang dimiliki investor asing untuk membuat perusahaan lebih maju atau berkembang lagi yaitu dengan melakukan ekspansi atau membuka cabang perusahaan yang baru. Investor asing dapat memberikan usulan dan pendapatnya melalui rapat yang diadakan perusahaan berkaitan dengan peningkatan nilai perusahaan. Investor asing berharap adanya keputusan pengambilan risiko perusahaan yang tinggi dapat menghasilkan return atau laba yang tinggi pula.

\subsubsection{Return On Asset (ROA)}

Sudana (2009) berpendapat bahwa perusahaan yang mempunyai profitabilitas tinggi, maka perusahaan tersebut efektif dalam menggunakan aktiva untuk menghasilkan laba dan dikategorikan perusahaan yang menguntungkan di masa yang akan datang. Sehingga investor tertarik menanamkan modalnya pada perusahaan tersebut. Wang (2010) menemukan hubungan yang positif antara free cash flow dengan kinerja keuangan yang menggunakan salah satu proksi ROA. Dapat disimpulkan bahwa perusahaan dengan tingkat laba yang tinggi maka perusahaan tersebut memiliki potensi free cash flow yang tinggi, dimana free cash flow tersebut digunakan untuk berinvestasi pada proyek-proyek yang menguntungkan. Tindakan manajer perusahaan agar menghasilkan laba yang tinggi dengan risk taking yaitu mengambil proyek yang berisiko tinggi. Ketika perusahaan memiliki 


\section{Indah Kurniawati}

Puput Tri Komalasari

tingkat laba cenderung menurun maka manajer perusahaan akan bertindak risk averse yaitu menghindari pengambilan proyek yang berisiko tinggi.

\subsubsection{Ukuran Perusahaan}

Ukuran perusahaan menunjukkan besar kecilnya perusahaan yang dapat dilihat dari tingkat penjualan, jumlah tenaga kerja atau jumlah aktiva yang dimiliki perusahaan tersebut. Rohman dan Utama (2013) menyatakan bahwa perusahaan yang memiliki aktiva yang besar atau ukuran perusahaan yang besar menunjukkan perusahaan tersebut sudah mencapai tingkat kemapanan (mature). Manajer perusahaan akan mempertahankan market share (pangsa pasar) perusahaan. Caranya dengan mengambil proyek-proyek investasi yang berisiko rendah, hal tersebut mencerminkan bahwa manajer perusahaan bersikap risk averse.

Bagi perusahaan yang memiliki aset yang kecil atau ukuran perusahaan yang kecil berada pada tahap growth (pertumbuhan) sehingga manajer perusahaan akan bertindak agresif dalam pengambilan suatu proyek investasi, agar perusahaan yang sedang bertumbuh tersebut bisa survive (bertahan). Hal tersebut diindikasikan dengan manajer perusahaan akan bertindak risk taking yaitu pengambilan proyek yang berisiko tinggi. Zeitun dan Tian (2007) melakukan pengukuran dengan menghitung natural logarithm (Ln) dari total aset yang memiliki ukuran relatif besar dibandingkan perusahaan dengan nilai aset yang kecil.

\section{Metode Penelitian}

\subsection{Metode Seleksi dan Pengumpulan Data}

Pada penelitian ini menggunakan populasi dari perusahaan non keuangan yang go public dan terdaftar di Bursa Efek Indonesia (BEI) periode tahun 2010-2013. Teknik penentuan sampel dalam penelitian ini adalah dengan metode purpose sampling yang merupakan metode pengambilan sampel tidak acak. Metode ini digunakan untuk memperoleh batasan-batasan dan kesesuaian dengan tujuan penelitian ini. Berdasarkan objek penelitian, maka penulis menetapkan kriteria pemilihan sampel yang diteliti sebagai berikut : (a) Perusahaan yang dipilih yaitu non keuangan, (b) Perusahaan yang memiliki kepemilikan negara dan/ atau kepemilikan asing yang terdaftar di Bursa Efek Indonesia periode tahun 2010-2013, (c) Perusahaan yang menerbitkan laporan keuangan terus menerus selama periode penelitian yaitu 2010-2013, (d) Perusahaan yang sudah IPO minimal tahun 2007, (e) Perusahaan yang melaporkan laporan keuangan dengan satuan nilai mata rupiah. 


\subsubsection{Jenis dan Pengukuran Variabel}

\section{Tabel 3.1}

Jenis dan Pengukuran Variabel

\begin{tabular}{|c|c|c|}
\hline $\begin{array}{c}\text { Jenis } \\
\text { Variabel }\end{array}$ & Variabel & Rumus Perhitungan \\
\hline Independen & $\begin{array}{l}\text { Kepemilikan } \\
\text { Negara } \\
\text { (STATEOWN) }\end{array}$ & 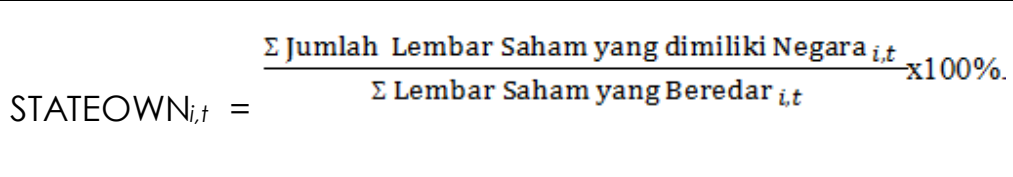 \\
\hline Independen & $\begin{array}{l}\text { Kepemilikan } \\
\text { Asing } \\
\text { (FOREIGN } \\
\text { OWN) }\end{array}$ & $\begin{array}{l}\text { FOREIGNOWN } N_{i, t} \\
=\frac{\sum \text { Jumlah Lembar Saham yang dimiliki Investor Asing } i, t}{\sum \text { Lembar Saham yang Beredar } i, t} \times 100 \%\end{array}$ \\
\hline Dependen & $\begin{array}{l}\text { Corporate } \\
\text { Risk Taking } \\
\text { (RISK) }\end{array}$ & $\begin{array}{l}\text { RISK } K_{i, t}=\sqrt{\frac{1}{T-1} \sum_{\mathrm{t}=1}^{\mathrm{T}}\left(E_{i, t}-\frac{1}{T} \sum_{\mathrm{t}=1}^{\mathrm{T}} E_{\mathrm{i}, \mathrm{t}}\right) 2} \\
\text { dimana } E_{i, t}=\frac{E B I T_{i, t}}{A_{i, t}}\end{array}$ \\
\hline Kontrol & $\begin{array}{l}\text { Return On } \\
\text { Asset (ROA) }\end{array}$ & $\mathrm{ROA}_{\mathrm{i}, t}=\frac{\text { laba bersih setelah pajak }_{i, t}}{\text { total aset }_{i, t}}$ \\
\hline Kontrol & $\begin{array}{l}\text { Ukuran } \\
\text { Perusahaan } \\
\text { (SIZE) }\end{array}$ & Ukuran perusahaan $_{i, t}=$ Ln total aset $t_{i, t}$ \\
\hline
\end{tabular}

\subsubsection{Metode Analisis Data}

Teknis analisis yang digunakan pada penelitian ini adalaha analisis regresi linier berganda (Multiple Linier Regression Analysis) dengan tingkat signifikansi (a $=5 \%$ ) menggunakan data panel (pooled data). Analisis linier berganda digunakan untuk menjawab hipotesis yang telah diajukan. Metode analisis ini digunakan untuk menjelaskan hubungan antara dua variabel bebas (independent variable) atau lebih terhadap satu variabel terikat (dependent variable). Berdasarkan model regresi linier berganda dan hipotesis penelitian maka model analisis yang digunakan dalam penelitian ini adalah regresi data panel. Adapun model persamaan yang digunakan untuk menguji hipotesis adalah sebagai berikut:

(1) RISK $K_{i, t}=\alpha_{0}+\beta_{1}$ STATEOWNi,t $_{i}+\beta_{3} R O A_{i, t}+\beta_{4}$ SIZE $_{i, t}+e_{i, t}$

(2) RISK $_{i, t}=\alpha_{0}+\beta_{2}$ FOREIGNOWN $N_{i, t}+\beta_{3} R_{\text {ROA }}{ }_{i, t}+\beta_{4}$ SIZE $_{i, t}+e_{i, t}$ 
Indah Kurniawati

Puput Tri Komalasari

Keterangan:

RISK $=$ corporate risk taking (volatilitas laba) perusahaan $i$ pada tahun ke $\dagger$

$\alpha_{0}$

$=$ konstanta model regresi

$\beta_{1} \ldots \ldots . . . B_{2}$

= koefisien regresi masing-masing variabel

STATEOWNi,t

$=$ kepemilikan negara perusahaan $\mathrm{i}$ pada tahun ke $\dagger$

FOREIGNOWNi,

$=$ kepemilikan asing perusahaan $i$ pada tahun ke $\dagger$

$R O A_{i, t}$

$=$ return on asset perusahaan i pada tahun ke $t$

$S I Z E_{i, t}$

$=$ ukuran perusahaan perusahaan $i$ pada tahun ke $t$

$e_{i, t}$

$=$ nilai eror

\section{Hasil dan Pembahasan}

\subsection{Hasil Analisis Penelitian}

Berdasarkan data dari variabel-variabel yang telah diukur dan sudah dilakukan uji asumsi klasik, maka perlu dilakukan analisis untuk mengetahui pengaruh variabel independen terhadap dependen. Hasil uji regresi yang menguji pengaruh variabel independen, yaitu STATEOWN dan FOREIGNOWN serta variabel kontrol ROA dan SIZE terhadap corporate risk taking (RISK) yang diukur dengan menggunakan proksi volatilitas laba adalah sebagai berikut:

Tabel 4.1

Hasil Regresi Linier Berganda

Pada Regresi 1 (Kepemilikan Negara)

\begin{tabular}{|c|c|c|c|c|c|c|c|c|}
\hline \multirow{2}{*}{$\begin{array}{c}\text { Variabel } \\
\text { Depende } \\
n\end{array}$} & \multirow{2}{*}{$\begin{array}{c}\text { Variabel } \\
\text { Independe } \\
n\end{array}$} & \multirow[b]{2}{*}{ Koefisien } & \multicolumn{3}{|c|}{ Uji $\dagger$} & \multicolumn{3}{|c|}{ Uji F } \\
\hline & & & $\begin{array}{c}\dagger \\
\text { hitung }\end{array}$ & Sig & Hasil & F hitung & Sig & Hasil \\
\hline \multirow{4}{*}{ RISK } & Constant & 37,418 & 3,056 & 0,005 & & \multirow{4}{*}{10,660} & \multirow{4}{*}{0,000} & \multirow{4}{*}{ sig } \\
\hline & STATE OWN & $-0,067$ & $-2,672$ & 0,012 & signifikan & & & \\
\hline & ROA & 0,281 & 5,632 & 0,000 & signifikan & & & \\
\hline & SIZE & $-1,094$ & $-2,931$ & 0,006 & signifikan & & & \\
\hline \multicolumn{9}{|c|}{ Tingkat Signifikansi $(\alpha): 0,05$} \\
\hline \multicolumn{9}{|l|}{$R: 0,707$} \\
\hline \multicolumn{9}{|l|}{$R^{2}: 0,500$} \\
\hline
\end{tabular}


Tabel 4.2

Hasil Regresi Linier Berganda

Pada Regresi 2 (Kepemilikan Asing)

\begin{tabular}{|c|c|c|c|c|c|c|c|c|}
\hline \multirow{2}{*}{$\begin{array}{c}\text { Variabel } \\
\text { Depende } \\
n\end{array}$} & \multirow{2}{*}{$\begin{array}{c}\text { Variabel } \\
\text { Independe } \\
\text { n }\end{array}$} & \multirow[b]{2}{*}{ Koefisien } & \multicolumn{3}{|c|}{ Uji † } & \multicolumn{3}{|c|}{ Uji F } \\
\hline & & & $\begin{array}{c}\dagger \\
\text { hitung }\end{array}$ & Sig & Hasil & $\begin{array}{c}\mathrm{F} \\
\text { hitung }\end{array}$ & Sig & Hasil \\
\hline \multirow{5}{*}{ RISK } & Constant & 10,368 & 6,369 & 0,000 & & \multirow{5}{*}{11,539} & \multirow{5}{*}{0,000} & \multirow{5}{*}{ sig } \\
\hline & FOREIGNO & 0,008 & 2,360 & 0,019 & signifikan & & & \\
\hline & WN & & & & & & & \\
\hline & $\mathrm{ROA}$ & 0,029 & 2,810 & 0,005 & signifikan & & & \\
\hline & SIZE & $-0,265$ & $-4,574$ & 0,000 & signifikan & & & \\
\hline \multicolumn{9}{|c|}{ Tingkat Signifikansi $(\alpha): 0,05$} \\
\hline \multicolumn{9}{|l|}{$R: 0,235$} \\
\hline \multicolumn{9}{|l|}{$R^{2}: 0,055$} \\
\hline
\end{tabular}

Koefisien regresi penelitian menunjukkan tanda yang bervariasi, yaitu positif dan negatif. Koefisien bertanda positif menunjukkan perubahan yang searah antara variabel bebas terhadap variabel terikat, sedangkan koefisien yang bertanda negatif menunjukkan arah perubahan yang berlawanan antara variabel bebas terhadap variabel terikat. Berdasarkan table 4.1 STATEOWN berpengaruh signifikan dengan arah negatif terhadap corporate risk taking sedangkan tabel 4.2 FOREIGNOWN berpengaruh signifikan dengan arah positif terhadap corporate risk taking. Pada tabel 4.1 dan 4.2 dapat disimpulkan bahwa ROA berpengaruh signifikan dengan arah positif terhadap corporate risk taking sedangkan SIZE berpengaruh signifikan dengan arah negatif terhadap corporate risk taking.

Hasil uji F untuk meneliti pengaruh kepemilikan negara dan kepemilikan asing secara bersama-sama terhadap corporate risk taking. Tabel 4.1 dan 4.2 menunjukkan nilai signifikansi uji F sebesar 0,000, dimana nilai tersebut di bawah dari nilai $\alpha=0,05$. Ini berarti bahwa kepemilikan negara dan kepemilikan asing secara bersama-sama berpengaruh signifikan terhadap corporate risk taking yang diukur dengan volatilitas laba.

Uji koefisien determinasi dilakukan untuk mengetahui seberapa besar variabel bebas (independent) dapat menjelaskan variabel terikat (dependent). Berdasarkan tabel 4.1 dan 4.2 diperoleh nilai koefisien determinasi (R Square) untuk model sebesar 0,500 atau $50 \%$ dan 0,055 atau 5,5\%. Hasil dari regresi 1 (kepemilikan negara) menunjukkan bahwa variabel kepemilikan negara dan variabel kontrol yaitu ROA dan ukuran perusahaan mampu menjelaskan sebesar $50 \%$ variasi perubahan volatilitas laba sebagai proksi dari corporate risk taking dan sisanya 50\% dipengaruhi oleh variabel-variabel lain di luar penelitian ini. Hasil dari regresi 2 (kepemilikan asing) menunjukkan bahwa variabel kepemilikan asing dan variabel kontrol yaitu ROA dan Ukuran perusahaan mampu menjelaskan sebesar 5,5\% variasi 


\section{Indah Kurniawati}

Puput Tri Komalasari

perubahan volatilitas laba sebagai proksi dari corporate risk taking dan sisanya $94,5 \%$ dipengaruhi oleh variabel-variabel lain di luar penelitian ini

\subsection{Pembahasan}

\subsubsection{Pengaruh Kepemilikan Negara Terhadap Corporate Risk Taking}

Berdasarkan hasil uji pengujian $t$, diperoleh hasil bahwa kepemilikan negara berpengaruh negatif signifikan terhadap corporate risk taking dengan indikator pengukuran volatilitas laba. Hasil tersebut tidak sesuai dengan penelitian yang dilakukan oleh Boubakri et al. (2013) dan Boycko, Shleifer dan Vishny (1996) yang menghasilkan bahwa kepemilikan negara berpengaruh negatif tidak signifikan terhadap corporate risk taking. Hal tersebut menunjukkan bahwa semakin besar kepemilikan saham negara yang diwakili oleh pemerintah, maka akan menurunkan nilai volatilitas laba yang diperoleh, dikarenakan manajemen perusahaan lebih menghindari risiko yang tinggi (risk averse).

Pemerintah dapat mengintervensi kinerja perusahaan demi kepentingan pemerintah semata. Pemerintah biasanya melakukan intervensi dalam perdagangan dengan mendukung perusahaan-perusahaan domestik dalam kegiatan ekspor. Motif-motif yang mendasari pemerintah melakukan intervensi dalam perdagangan domestik yang paling utama yaitu motif politik dan lainnya pada kegiatan ekonomi, sosial dan budaya. Politik mendorong pemerintah untuk melakukan berbagai kebijakan seperti melindungi pekerja, melindungi keamanan nasional, sebagai respon terhadap kebijakan perdagangan negara lain yang tidak adil dan mempengaruhi negara-negara lain, dengan begitu maka pemerintahan yang sedang berkuasa mendapatkan kembali hati rakyatnya ketika pemilihan umum selanjutnya (Daniels, et.al. 2007: 172). Selain itu, untuk alasan sosial dan budaya bahwa budaya umumnya suatu negara dapat terpengaruh dari adanya keterbukaan saling berinteraksi dan berkaitan. Ketika suatu bentuk kebudayaan tidak diinginkan maka pemerintah dapat melakukan pencegahan dengan cara menghalangi masuknya produk impor. Pada kegiatan ekonomi dimana pemerintah mengintervensi pasar sebagai upaya untuk melindungi industri-industri kecil dan menengah dari kompetisi serta bentuk promosi sebagai kebijakan strategi perdagangan dan intervensi dari pemerintah yang kuat menyebabkan manajemen perusahaan untuk mengambil investasi yang konservatif yaitu investasi yang mengandung suatu risiko yang rendah meskipun keuntungan yang didapatkan juga rendah.

\subsubsection{Pengaruh Kepemilikan Asing Terhadap Corporate Risk Taking}

Hasil regresi pada kepemilikan asing dapat diketahui bahwa kepemilikan asing mempunyai pengaruh positif signifikan terhadap corporate risk taking dengan indikator pengukuran volatilitas laba. Hasil signifikan tersebut tidak sesuai dengan penelitian Nguyen, P. (2011) dan penelitian Boubakri et al. (2013). Hal ini berarti semakin banyak kepemilikan asing dalam suatu perusahaan maka akan meningkatkan pengambilan proyek yang lebih 


\section{Jurnal Manajemen Teori dan Terapan \\ Tahun 7. No.2, Agustus 2014}

berisiko. Investor asing dapat meningkatkan tata kelola perusahaan dan manajerial dalam pengambilan risiko (John, Litov dan Yeung, 2008).

Perusahaan dengan mayoritas kepemilikan asing memiliki manajemen perusahaan yang lebih agresif atau risk taking sehingga berani untuk mengambil risiko yang tinggi dengan harapan keuntungan yang didapatkan juga tinggi. Keberanian tersebut juga diimbangi dengan kemampuan, keahlian, pengetahuan dan kecanggihan teknologi yang dimiliki investor asing untuk membuat perusahaan lebih maju atau berkembang lagi yaitu dengan melakukan ekspansi atau membuka cabang perusahaan yang baru. Peran investor asing dalam perusahaan melalui rapat yang diadakan perusahaan berkaitan dengan peningkatan nilai perusahaan. Investor asing dapat memberikan usulan atau pendapatnya ketika perusahaan akan mengambil suatu proyek atau investasi. Keberanian pihak manajer perusahaan untuk mengambil proyek atau investasi yang beresiko tinggi didukung oleh adanya investor asing berdasarkan kelebihan yang dimiliki investor asing dibandingkan investor lokal.

\subsubsection{Pengaruh Return on Asset (ROA) terhadap Corporate Risk Taking}

Hasil regresi 1 (kepemilikan negara) pada return on asset (ROA) menunjukkan bahwa ROA berpengaruh positif signifikan terhadap corporate risk taking dengan indikator pengukuran volatilitas laba. Hasil penelitian tersebut tidak sesuai dengan Boubakri et al. (2013) dan Nguyen, P. (2011) menunjukkan bahwa ROA berpengaruh negatif tidak signifikan terhadap pengambilan risiko perusahaan atau standar deviasi ROA. Hasil regresi 2 (kepemilikan asing) pada return on asset (ROA) menunjukkan bahwa ROA berpengaruh positif signifikan terhadap corporate risk taking dengan indikator pengukuran volatilitas laba. Hasil penelitian tersebut sesuai dengan Boubakri et al. (2013) namun berbeda dengan Nguyen, P. (2011) yang menunjukkan bahwa ROA berpengaruh negatif tidak signifikan terhadap pengambilan risiko perusahaan atau standar deviasi ROA. Sesuai dengan penelitian yang dilakukan Wang (2010) menemukan hubungan yang positif antara free cash flow dengan kinerja keuangan yang menggunakan salah satu proksi ROA.

Dapat disimpulkan bahwa perusahaan dengan tingkat laba yang tinggi maka perusahaan tersebut memiliki potensi free cash flow yang tinggi, dimana free cash flow tersebut digunakan untuk berinvestasi pada proyek-proyek yang menguntungkan. Tindakan manajer perusahaan agar menghasilkan keuntungan yang tinggi dengan risk taking yaitu mengambil proyek yang berisiko tinggi yang tercermin dari nilai volatilitas laba yang tinggi. Ketika perusahaan memiliki tingkat laba cenderung menurun maka manajer perusahaan akan bertindak risk averse yaitu menghindari pengambilan proyek yang berisiko tinggi. Hal tersebut tercermin dari nilai volatilitas laba yang rendah. Investor harus bisa membaca investasi suatu perusahaan memiliki risiko yang tinggi atau rendah dilihat dari tren laba bersih perusahaan. Investor akan mengharapkan suatu return yang tinggi, karena tingginya ROA 


\section{Indah Kurniawati}

Puput Tri Komalasari

juga menggambarkan laba bersih sesudah pajak yang merupakan hak bagi pemilik atau pemegang saham juga tinggi.

\subsubsection{Pengaruh Ukuran Perusahaan Terhadap Corporate Risk Taking}

Hasil regresi 1 (kepemilikan negara) dan regresi 2 (kepemilikan asing) pada ukuran perusahaan (SIZE) menunjukkan bahwa SIZE berpengaruh negatif signifikan terhadap corporate risk taking dengan indikator pengukuran volatilitas laba. Hasil penelitian tersebut tidak sesuai dengan Nguyen, P. (2011) dan Boubakri et al. (2013) yang menunjukkan bahwa ukuran perusahaan berpengaruh negatif tidak signifikan terhadap pengambilan risiko perusahaan atau standar deviasi ROA. Sesuai dengan penelitan Rohman dan Utama (2013) menyatakan bahwa perusahaan yang memiliki aktiva yang besar atau ukuran perusahaan yang besar menunjukkan perusahaan tersebut sudah mencapai tingkat kemapanan (mature).

Ketika suatu perusahaan dinilai mempunyai aktiva yang besar akan memunculkan pandangan bagi investor bahwa berinvestasi di perusahaan dengan tingkat aktiva besar memiliki risiko yang lebih kecil sehingga banyak investor yang ingin berinvestasi di perusahaan tersebut. Manajer perusahaan akan mempertahankan market share (pangsa pasar) perusahaan. Caranya dengan mengambil proyek-proyek investasi yang berisiko rendah, hal tersebut mencerminkan bahwa manajer perusahaan bersikap risk averse dan diindikasikan dengan nilai volatilitas laba yang rendah.

Bagi ukuran perusahaan yang kecil memiliki aset yang kecil juga dan berada pada tahap growth (pertumbuhan) sehingga manajer perusahaan akan bertindak agresif dalam pengambilan suatu proyek investasi, agar perusahaan yang sedang bertumbuh tersebut bisa survive (bertahan). Hal tersebut diindikasikan dengan manajer perusahaan akan bertindak risk taking yaitu pengambilan proyek yang berisiko tinggi dan diindikasikan dengan nilai volatilitas laba yang tinggi.

\section{Kesimpulan}

Berdasarkan hasil analisis dan pembahasan pada penelitian ini dapat ditarik kesimpulan bahwa :

1. Kepemilikan negara berpengaruh negatif signifikan terhadap corporate risk taking.

2. Kepemilikan asing berpengaruh positif signifikan terhadap corporate risk taking.

3. Return on Asset (ROA) berpengaruh positif signifikan terhadap corporate risk taking.

4. Ukuran perusahaan berpengaruh negatif signifikan terhadap corporate risk taking. 


\section{Daftar Refrensi}

Boubakri, N. et al, 2013. The role of state and foreign owners in corporate risk-taking: Evidence from privatitation. Journal of Financial Economics 108, 641-658.

Boycko, M., Shleifer, A., Vishny, R., 1996. A theory of privatitation. Economic Journal 106, 309319.

Budiman, Judi dan Setiyono. 2012. Pengaruh Karakter Eksekutif Terhadap Penghindaran Pajak (tax Avoidance). Electronic Theses \& Dissertations (ETD) Universitas Gajah Mada.

Dickinson, D.G. and Mullineux, A.W., 2001. Lessons from the East Asian financial crisis: a financial sector perspective. Georforum, 32(1): 133-142.

Fama, Eugene F., and Michael C. Jensen. 1983. Agency Problems and Residual Claims. Separation of Ownership and Control. Journal of Law and Economics, Vol. 26, No. 2, 301 325.

Fauzi, A. 2006. Struktur kepemilikan saham asing di Indonesia. Gramedia Pustaka Utama. Jakarta.

Ghozali, H. Imam. 201 1. Aplikasi Analisis Multivariate Dengan Program IBM SPSS 19. Semarang: Badan Penerbit Universitas Diponegoro.

Jensen, M. Dan W. H. Meckling. 1976. Theory of the firm : managerial behaviour, agency cost, and ownership structure, journal of financial and quantitative analysis, vol. 27, no. $22,247-263$.

John D. Daniels, Lee H. Radeburgh \& Daniel P. Sullivan. 2007. "Business-Government Trade Relations" dalam International Business: Environment and Operations. New Jersey: Pearson Prentice Hall.

John, K., L. Litov, and B. Yeung. 2008. Corporate governance and risk-taking. Journal of Finance 63, 1679-1728.

Kurniawati, Indah dan Puput Tri Komalasari, (2015), Pengaruh Kepemilikan Negara dan Asing Terhadap Corporate Risk Taking, Prodi S1 Manajemen Unair.137.

Nguyen, P., 2011 . Corporate governance and risk-taking: Evidence from Japanese firms.

Pacific Basin Finance Journal 19, 278-297.

Rohman, Abdul dan Tito Albi Utama. 2013. Pengaruh Corporate Governance Perception Index, Profitabilitas, Leverage, dan Ukuran Perusahaan Terhadap Nilai Saham. Diponegoro Journal of Accounting. Vol.2. No.2. hal 1-9.

Shen, Wei and Chen Lin. 2009. "Firm Profitability, State Ownership, and Top Management Turnover at the Listed Firms in China: A Behavioral Perspective", Blackwell Publishing Ltd, Corporate Governance: An International Review, Volume 17 Number 4 July 2009, 443456.

Shleifer, A., and Vishny, R.W., 1997. A survey of corporate governance. Journal of Finance 52, 737-777. 
Sudana, I. M. 2009. "Manajemen Keuangan Teori dan Praktek", Airlangga University Press, Surabaya.

Wang, George Yungchih. 2010. The Impact of Free Cash Flow and Agecy Cost on Firm Performence. Journal Service Science \& Management, 3, 408-418.

Zeitun, R dan G. Gang Tian. 2007. Does Ownership Affect a Firm's Performance and Default Risk in Jordan. Journal of Corporate Governance, 7: 66-82.

http://www.bei.co.id//

http://www.ksei.co.id// 